\title{
Discreet Performances, Anonymous Performances, Virtual Performances
}

\section{Cover Page Footnote}

This paper is part of the research "Virtual theater". Grant\#2015/17610-1, São Paulo Research Foundation (FAPESP). 


\section{Discreet Performances}

"Discreet work" is the term used by Quentin Jouret ${ }^{1}$ to describe the intervention entitled Placing Pillows, held in Mexico City in 1985, in which Francis Alÿs arranged a series of pillows in windows broken by an earthquake, with the announced intent of "opening a breach in the everyday fabric of the city." Although Jouret did not use the term in a classificatory sense, throughout this article I will use the term "discreet performance" to describe any action that-just like Placing Pillows - is performed without big, spectacular artifices, inscribing itself in the everyday in an almost transparent fashion, and whose artistic validation depends ultimately on an a posteriori discourse. It is the case with Wolfie, an action allegedly carried out by Nate Hill in New York's Central Park in 2012: according to the 'eyewitness account' of Whitney Kimball, published on the artist's website,

Mr. Hill quickly produced the burial object from his small black plastic bag: two sets of taxidermied egret legs, sewn together. They were joined by a small, furry ball with fang-like armadillo fingers poking out of it. 'There's some cat in there,' he noted. The intended burial site was in Sheep Meadow, a field which is closed to Park visitors after dusk, so we'd come prepared to jump a fence ... I handed Nate my bag, he gave me the leg-up, and we swung over the fence. Nate pulled off his shirt, kicked off his sneakers, and snapped on a Wolfman mask in the style of the 1941 film. We took a good ten to fifteen fast paces out into the open field, then Nate hunched down and dug furiously, first with the trowel, then with his hands. As I snapped flash photos, Nate froze and looked around at the park, then up at the full moon, which happened to be exactly behind his head, emerging behind parting clouds-much like a wolf, keeping one eye open for hunters as he devours his prey ... I returned the following afternoon: Sunday, September 2nd, around 3 PM. The park was now full of shirtless men playing frisbee and couples on towels ... After about twenty minutes searching the lawn, tapping dips with my shoe to make sure they were solid, I thought I'd lost the gravesite. I walked back toward the rock where Nate had left his shoes and shirt to exit through the west gate, which we had climbed over the night before. Then I saw it: a small pile of loose, dry dirt with a clump of grass next to it, just five feet or so in front of a couple on a towel. 'That's it!' I said aloud, pointing and running toward it. The couple looked on as I crunched down to inspect the hole. I was too afraid to run my hands into it, realizing that this could just as easily be a fresh dog pile. $^{2}$ 
In the case of both Alÿs and Hill, the traditional expectation of performance as "direct confrontation, and in the present, between the artist and his/her public" is questioned. Even the adjective "discreet" does not seem quite appropriate, since the actions in question would have been even more discreet if there was no record whatsoever of them. ${ }^{4}$ More important than seeking an essentialist definition of a concept that encompasses all experiences similar to those, is noticing how this kind of action helps us to understand better the role of critical and narrative discourses in the configuration of the works. Both in the case of Placing Pillows as Wolfie's, the account of the action is not an accessory or complementary element to the artistic performance; rather, it is what makes the work be recognizable as a performance. Perhaps we should ask ourselves how many passers-by were able to notice the pillows discreetly placed by Francis Alÿs in the broken windows. To a large extent, the "poetic moment" propitiated by the work remains in the field of fictional virtuality, and only exists thanks to the elements supposedly para-artistic (that are neverthless essential so that the performance does not go completely unnoticed): the propositions and the photographs taken by the artist himself, which not only record the interventions in question but also propose "authorized" interpretations, and the critical discourses woven for their most part from these records-and not from the performance per se.

In the case of Placing Pillows, we can identify three distinct performative instances: the arrangement of pillows in the windows; the subsequent publication/disclosure of the work by the artist, through photographs and comments; finally, the different critical discourses that will reconfigure the work to a wider audience. In varying degrees, all three instances are creative: the photographs not only document facts but give them certain determined framings that will be decisive in the becoming of the artistic work; the images put the reader in the position of a spectator, theatricalizing Alÿs's intervention in the urban space; in a similar fashion, the critical discourses produced by the artist and his commentators will provide interpretation keys for the future admirers of the work. Despite Jouret's claim that this kind of artistic practice would displace art to "beyond the museum,"5 it needs the official mechanisms (photographic records, critical reviews and the artist's own discourse) to legitimate it as a work of art. The simple action is not enough, and the artist himself seems to realize this by producing a series of discourses (or "narrations," as they are 
called by Van Beek ${ }^{6}$ ) as an mandatory complement to his/her "strictly artistic" work. Similarly, in Narcoturism (1996), Alÿs's wanderings through the streets of Copenhagen while under the influence of different drugs could have gone unnoticed had not the artist meticulously recorded his moments of semi-consciousness. ${ }^{7}$

In Wolfie, the inclusion of a witness theatricalizes the action, which takes place under the framing of an accomplice viewer. Concurrently, the fact that it is an "authorized witness," a friend of the $\operatorname{artist}^{8}$, attests to the performer's zeal for maintaining control over the work's interpretative potential. The fact that the report on the action is disclosed by Nate Hill himself on his personal website corroborates this traditional aspect of the author's figure. The actions of the artist in Central Park are only the first performative instances of the work, which needs two other moments (the witness's narrative and the reading of this narrative by a third party) so that it can be fulfilled as an artistic performance.

The same observations can be applied to other performances that took place without the presence of an audience, such as Disappearing, carried out by Chris Burden (December 22-24, 1971), in which it becomes clear the paradoxical character of this kind of "ostentatious discretion." If the artist limited himself to disappearing, the action would be fulfilled only in his inner circle and could not be characterized as an artistic performance; for this to occur, the artist must make visible his invisible action - through a narrative or some other form of objectification. As Fourgeaud notes, "the disappearances staged by the artist are systematically retraced by a written report, but also sometimes by means of an oral presentation, as in BC Mexico (1973), in which he goes into voluntary exile on a desert island during a period of scorching heat, taking the precaution of announcing beforehand his disappearance through his gallery and returning a few days later, to give the account of his expedition before an audience." 9

\section{Anonymous Performances}

Carried out from 1976 on by Jacques Lennep, the actions entitled Museum of Man had the explicit purpose of "presenting in galleries and museums people who were not artists recognized as such, but who made of their existence a space of creation." ${ }^{10}$ This creativity did not necessarily manifest itself in the production of objects strictly considered as artistic ones, but could reveal itself in the most 
diversified fields, such as gestures, costumes or ways of speaking. One example among many is the Italian Ezio Bucci's:

Ezio Bucci exchanges his hometown of Montegallo, in the Marche, for Belgium in 1951. Like many Italians expelled by poverty, he goes to work there as a miner ... Bucci wants to be the supporter par excellence. During the matches, he dresses from head to toe in the colours of his team. He dresses "zebra," according to his own expression. His wardrobe is full of striped items: jackets, trousers, overalls, scarves, ties ... not to mention his various accessories: umbrellas, megaphones, banners, flags. Today, in view of the ridiculous and delirious costumes of the fans, this may seem banal. At the time, Bucci is a precursor. ${ }^{11}$

The excerpt above the performative effect played by the critical-narrative text: far from simply a "document," a "raw datum" of reality, the critic-rhapsode ${ }^{12}$ carefully elaborates his character by selecting data that in another time will serve as justification to his theorization (the fact that Bucci works as a miner, for example, will be a starting point for the metaphorical game between "light" and "darkness"). The displacement of the artistic lexicon ("precursor") to the everyday sphere complements the displacement of the everyday actions to the artistic sphere (in a clear dialogue with the practice of the ready-made inaugurated by Marcel Duchamp).

The statement that "in their everyday lives, some of these people, ignoring all about avant-garde art (as well as about art in general), carried out performances comparable to those of recognized artists" $" 13$ underpins the idea that what makes the performance an artistic object is not its concrete accomplishment, but its insertion into a discursive field. The performative aspect of the critical discourse becomes more evident in the following excerpt:

Bucci's performance is meaningful on symbolic and social level. It is carried out as a ritual by an émigré who had to abandon a sunny country to extract coal at the bottom of a mine. His passion for the spherical ball (a solar symbol) allows him to dream of a salvation: get out of the mine, escape from a painful condition. The white (light) and the black (darkness) are the contrasting expression of this obsession. Bucci's performance is equally interesting on an artistic level. The supporter indeed practices the stripes ten years before they are systematized by Daniel Buren. Contrary to Buren, who will make his trademark stripes in the name of art, exclusively in his context and theorizing his action, Bucci does it by instinct, in his own life, applying the stripe to his own person, his close ones, his home and within a social group in a sporting event. $^{14}$

Here too, as in Wolfie, it is patent the "authorial" character of a discourse that is intended to guide the reader/spectator in his relation to the "work." This authority 
becomes more evident by the fact that the artistic object event exists only as an effect of that very same discourse which, by putting into practice Austin's definition regarding performative acts, "does what it says to do just by saying it." 15 More than authorial, we can glimpse an authoritarian bias in the characterization of Bucci's acts as "instinctive," linking it surreptitiously to the animal sphere and re-establishing an old dichotomy between the supposedly "passionate" and "authentic" action of the "raw artist" and the critic's "enlightened" and enlightening discourse.

A closer observation of the process, however, dismantles this simplistic dichotomy. Lennep himself acknowledges that Ezio Bucci "has studied industrial design." 16 The fact that the performance is not held with the fundamental intention of inclusion in an artistic field does not automatically characterizes it as an instinctive act, since it is a case of deliberate, purposeful activity with a rational goal: to demonstrate and proclaim Bucci's affective and social bonds to the team in question. On the other hand, the complex relationships between observation and creation present in Lennep's discourse can be extended to all critical discourse/evaluation about a work of art: it is not simply a matter of describing or revealing something that "was already there"; what is also at stake here is setting up an experience that only achieves artistic status thanks to the critical discourse.

In this sense, more than revealing the latent artistic nature of certain everyday gestures, the Museum of Man unveils the artistic and performative character of the critical discourse, which (to a greater or lesser extent) is always a creative act. This observation can be substantiated by a practical experiment. Let us take as a starting point a newspaper report on a recent concrete actual fact:

Veiga Filho Street in Higienópolis, a fancy neighborhood in the central region of São Paulo city, received this week an unusual resident. Six days ago, Pedro (his assumed fictitious name) housed himself on the top of a tree at the number 105 and became part of the landscape, visible to anyone who passes by that street. Sixteen years old, black, without personal documents and without family, the boy recounts the epic journey of how he got out of Cachoeira de Macacu (a small town in the state of Rio de Janeiro), and made it to his new nest after his father's death and his mother's vanishing. He says he hid amid the cargo of a car carrier truck [in Brazil, these car haulers are called caminhões-cegonha, or literally 'stork-trucks'] and arrived in São Paulo. In his luggage Pedro carries a pillow, a duvet and a plastic bag with a shirt and a pair of jeans. He also carries a copy of the Practical Encyclopedia of Magic and Illusionism, which Pedro says he cannot remember where he found. His dream is to be a magician, "those of cards," but since he can't read, he is waiting for someone who is able to teach him a few tricks. 
The house was no more than a few hedges and planks supported by the branches, which served as a base or mat so he could lie down at bedtime. The shelter had to be dismantled after the approach of the Military Police, called by the third time by some residents of the Santa Emília building, an apartment block just opposite the tree. The police officers advised the boy to remove his things and move out of the street. Since Pedro refused to, he was beaten by neighborhood residents who attended the scene. He ran away only to return the next day, very scared.

Retiree Luis Inácio Pio de Almeida, a joint owner of the Santa Emília building, gets annoyed by the presence of Pedro in the vicinity. For him, besides the risk of living on a tree, the boy may pose a threat to the residents. "He has not had a violent behaviour yet, but we don't know. I have even suggested that they tear down the tree to see if he goes away, since he settled up here and does not leave anymore," he blusters, rampaging from inside the building's chain-link fence. ${ }^{17}$

However much we observe some similarities between the facts described and the practices of certain contemporary artists, no journalist or critic, to date, has called attention to this resemblance. However, the simple transcription of this piece of news in an academic journal about performance art is enough to transform our point of view. Furthermore, we can develop a discourse that reinterprets the news in question as an artistic performance. We can point out that, similarly to performances such as Francis Alÿs's Railings, the action of the "Bird-Boy" (as he is called by the journalist) dilutes the boundary between the public and private spheres, questioning the citizens' perception about the urban space. His "foreign" body trangresses the "normal" functioning of the upper-class neighborhood. Because of his inability to be framed in clear categories, the Bird-Boy's figure destabilizes those same categories. Just like the emblematic figure of the Cynic philosopher Diogenes cited by Laguarda in her analysis of artistic performances in urban areas, the Bird-Boy's 'out of place' actions call into question the alleged 'social contract' that governs the urban space, revealing the gap and the mismatch between the ideal or perfect design of a 'sanitized' city and its concrete reality. ${ }^{18}$

Paraphrasing Lennep, we can say that the Bird-Boy's performance is meaningful on symbolic and social levels. His refusal to remain at ground level (manifested in the choice of a tree as his housing, but also in his fascination with magic), emphasized by the mythical narrative of his arrival in a car-carrying truck (in portuguese, a stork-truck, a hybrid figure of speech between the mechanical and the animal, the heavy and the light, the aerial and terrestrial), and by his very nickname- 
which refers to superhero figures of pop culture-represents a stark contrast to the prosaic concerns of the witnesses of his actions. We cannot help but also notice the symbolic implications of the association of the boy's image with fictional characters who played the same vertical act, such as The Baron in the Trees (Il barone rampante, the 1957 Italian novel by Italo Calvino), who also challenges the horizontal rules of everyday existence by deciding to live on top of a tree.

Lennep is a visual artist who documents and exhibits photographs of Bucci in an ongoing art work, whereas in this article I act as a theoretician who reads an anonimous act as an artistic performance - this is just a circumstantial difference: in both cases someone acts like a curator who ensures the visibility of a "work" that would not be perceived as art without this new disclosure; in both cases the way of perceiving the artfullness of an event is determined not by its intentionality, but by its framing. ${ }^{19}$

Besides that, all the elements that Pickels considers as the definers of performance art are present in the action of the Bird-Boy: "the taking of a risk (physical, intellectual, emotional, political ... ), the personal engagement in the act, the unique character of the performance (even though it repeats itself), the porosity to the presence of the other, the willingness to propose a moment which is watched not only by spectators, but by witnesses." ${ }^{20}$ Unlike Tino Sehgal—who in works like Diese Beschäftigung uses people in precarious social conditions, such as refugees, unemployed, and homeless persons ${ }^{21}$ — the Bird-Boy uses the very vulnerability of his own body as an instrument of his action. Thus, his intervention is much more daring than that of the artists who conjure up the 'nomadism' or the 'deterritorialization' as the predicate of their actions, since his helplessness (as a black child, an orphan, illiterate, 'disturbed' and out of the artistic sphere) does not find support in any form of auto-exegetical discourse.

If we compare the vulnerability of the Bird-Boy to the instructions of Nate Hill to his accomplice-witness ('Nate, still shirtless, said we'd just tell them [the policemen] that this was an art project. 'Don't tell them about the dead animal part. Just say I'm pretending to be a wolf burying things', he instructed, holding up the trowel'), the inscription of his risky and free acts into the artistic field has a derisive and even farcical flavour, as if we "hygienized" his subversively "impure" figure. 


\section{Virtual Performances}

"To transform the world into a stage for my actions"-with this motto, Australian Mark Canfell created his work, beginning with 2007's Play Dead, in which he simulates his own death; not on the stage, but through concrete actions: after sending letters to various friends announcing his suicide, he sets fire to his own car, puts in his place the body of a man with physical characteristics similar to his own, dresses in his clothes and wears his wedding ring. The actor is indeed presumed dead, and only reappears a month after his own funeral to announce the premiere of his play_or rather, the second part of his play_in which he tells the audience every detail of the staging, aided by photos and videos made by himself (including images of the funeral itself, which he attended discreetly disguised as a professional photographer), reports from friends and family, articles from newspaper and magazine clippings, and later from the court records for the fraud lawsuits he had to face.

In 2012's A Portrait of the Young Man as an Artist, Canfell opened his house for ten hours a day ("the most lucid and intense hours of my day") for six months, so that the spectators could follow "in real time" his creative process-which consisted essentially of waking up around noon, eating, playing video games or lying down until night fell and eating again and going back to sleep. Some spectators complained about the fact of not being able to see the actual concretization of a work, but as Malcolm McCallum sensibly pointed, "here, watching is creating the work," which consisted precisely in the spectators' anticipation of a work that was already there.

But it is with 2015's Stage of Fools that Canfell's project reaches the apex of its radicalization. Conceived as a drama-documentary carried out inside the Macquarie Hospital in North Ryde, the artist asked to be admitted as mentally ill. When his request was denied by the hospital management, Canfell performed a series of seemingly disparate acts - he ate dirt, defecated on a tree, ran naked through the streets of North Ryde, made drawings in his arm with a stylus - until he was finally taken into the hospital, and remains under medical treatement. All those who follow his work continue to expect the project's outcome, but so far the medical bulletins issued by the hospital's team of psychiatrists have been disheartening.

To the critic José Ángel Restrepo, "more than a type of performance art, theater or dance, the Potlatch Art is a genre apart, with its own irreducible specificities." In an article recently published in Theatre Inquiry, Nadja Saint-Gilles 
explains that "with the Potlatch Art, the boundaries between art, ritual and marketing are permanently erased." For more than ten years, however, Potlatch Art was practiced in small towns in both Canada and the United States without arousing great interest of either the public or art critics. One could find one scattered references to "exotic ritual" and "criptodadaists reenactments" in the local press, but the name of Tadzie Tlowitsis would have remained ignored, had not the Mexican billionaire Carlos Buxom become interested in Potlatch Art.

Held in June 2013, the performance (the ritual?) Sic Transit definitely placed Tadzie Tlowitsis in the ranks of great contemporary artists. The Potlatch Art in question consisted of a ritualistic dance performed by seventeen Pacific Northwest Coast indigenous inhabitants, the Kwakwaka'wakw, to the sound of electronic music beats sampled live by Tlowitsis himself. The center of the spectacle (the ceremony?), was neither the dancers nor the DJ, but Carlos Buxom's private jet-a Golfstream G550 estimated at about forty million dollars-which was being systematically destroyed by the actors (celebrants?) with stones, cudgels and spears as the choreography evolved. Although the performance witnessed by an extremely select audience (among them was the musician Sting, who defined the event as "an electrifying cultural shock"), the Potlatch Art happening, carried out in one of Buxom's rural properties, soon made it to the pages of major American newspapers.

From this moment on, Tlowitsis carried out Potlatchs in Dubai (where a luxurious 17-story building was built with the sole purpose of being ritually destroyed seventeen months later), Milan, Sydney and Osaka (where 800 hundred year-old ceramic pots were wrecked in a few seconds, in a ceremony entitled Impermanence, performed before seventeen Buddhist monks who merely observed in silence). Despite the artist's success, the invitation to participate in the Documenta 15 was cancelled after dozens of protests by German and Canadian activists unhappy with the fact that Tlowitsis had patented the genre, threatening to sue "any person or artistic community that imitated, copied or appropriated, explicitly or implicitly, the methods and rituals of Potlatch Art." The protests did not prevent seventeen pieces of Carlos Buxom's jet, signed by Tadzie Tlowitsis, being auctioned at the total value of 2.7 million dollars US.

From the moment the shared presence between the artist and the spectator is no longer considered decisive for the artistic effect of a work-as in the case of the "discreet performances" and the "anonymous performances"- the path is clear for 
critical and narrative discourse to create its own object, as in the virtual performances of Mark Canfell and Tadzie Tlowitsis. The fact that they are all fictional figures, and that there are therefore no concrete records of their achievements, does not make them less worthy of appreciation by critics. If we compare them with Nate Hill's actions, which we have access to only through his personal website, or with Ezio Bucci's or the Bird-Boy's performances, which only transmute themselves into performance art thanks to the validation of a foreign discourse, it becomes clear that "virtual performances" are only the radicalization of a recurring device in the criticism of contemporary art: the performativity of the critical and narrative discourse.

To affirm that virtual performances are "just literature" is as inaccurate and superficial as considering the photograph of Rudolf Schwarzkogler's alleged selfcastration $^{22}$ or Yves Klein's Leap Into the Void a "mere montage": the question posed from these examples concerns the very ontology of performance, whose overly simplistic view of actions and of the discursive elements or audiovisual documentation must be rethought. ${ }^{23}$ I do not endorse Auslander's concept according to which the actual, concrete accomplishment of performative acts is dispensable or secondary to the understanding of any performance; ${ }^{24}$ however, the practical experiment I have just performed by presenting fictional characters as authentic performers seems to demonstrate that the critical and narrative discourses woven around an action (be they produced by the artists themselves, or by professional critics or "lay" spectators) should not be overlooked, taken for granted or treated as mere transparent records - or even as "traces." ${ }^{25}$ In some cases, the artistic effect of a performance is the consequence of a discursive construction irreducible to any concrete effectuation. Pondering the performative effect of all critical or narrative discourse regarding an artistic action (actual or virtual) leads us to a redefinition of the center of the performance, which must be displaced from a concrete action to an indeterminate (and in some cases undecidable) place between the action, the document and the discourse. 
1 Quentin Jouret, “De la 'déculturation': l'art au-delà du musée," Alternatives théâtrales 116, (2013): 52.

${ }^{2}$ The complete account of the performance can be seen at http://www.sociopath.online /wolfie.

${ }^{3}$ Nicolas Fourgeaud, "La performance au miroir des médiations. Enjeux théoriques et critiques' (PhD diss., Université Paris 3, 2012), 346.

${ }^{4}$ Laguarda uses the term 'furtivité' (furtiveness) to characterize some of the Scoli Acosta's performances in which the individual action 'loses itself in the immensity and in the city's hustle and bustle' (Alice Laguarda, 'Performances artistiques et milieu urbain: urbanités et dissonances', Ligeia, 117-120 (2012), 189.

5 Jouret, 52.

${ }^{6}$ Paul Van Beek, 'The invention of a city. On the socio-political narrations of Francis Alÿs', in Design History Society Conference on Design Ativism (Barcelona, September 2011).

${ }^{7}$ Cf. Laguarda, 187.

${ }^{8}$ Procedure followed in performances 'without spectator' of other artists, as in Dead Man (11/12/1972), in which Chris Burden's 'stealthy' action is recorded by a photographer commissioned by the artist to document an event that otherwise could go unnoticed. For an analysis of the relationships between performance and document in this and other emblematic cases, I refer the reader to the brilliant study by Fourgeaud.

${ }^{9}$ Fourgeaud, 259.

${ }^{10}$ Jacques Lennep, “Performances et 'Musée de l'homme,' Ligeia, 117-120 (2012), 146.

${ }^{11}$ Ibid., 148.

${ }^{12}$ For the use of this term, see Marco Catalão, "Crítica e ficção na análise do teatro contemporâneo," Sala Preta 14, no. 2 (2014): 143-152, accessed May 5, 2016, doi: 10.11606/issn.2238-3867v14i2p143-152 and Marco Catalão, "Virtual Theater: Theory and Practice," Art Research Journal 3, no. 1 (2016): 92-106. Acessed September 10, 2016.

https://periodicos.ufrn.br/artresearchjournal/article/view/8203/6854.

${ }^{13}$ Lennep, 149.

${ }^{14}$ Ibid., 149. 
${ }^{15}$ Frédéric Landragin, "Compte rendu de lecture de l'ouvrage 'Les actes de langage dans le discours' de C. Kerbrat-Orecchioni," Bulletin de la Société Linguistique de Paris XCVIII, (2003): 2.

${ }^{16}$ Lennep, 148.

17 Vivian Codogno, 'Menino-passarinho' intriga moradores de Higienópolis. $O$ Estado de São Paulo, August 01, 2014.

${ }^{18}$ Laguarda, 191.

${ }^{19}$ Boris Groys, Art Power (Cambridge, MIT Press, 2008), 92-93, "today an author is someone who selects, who authorizes. Since Duchamp an author has become a curator ... Once the identity between creation and selection has been established, the roles of the artist and of the curator also become identical."

${ }^{20}$ Antoine Pickels, "Performance: de l'évasion du marché à la conformation au marché," Ligeia, (2012): 145.

${ }^{21}$ Katahrina Pewny and Simon Leenknegt, "La précarité dans la performance Diese Beschäftigung de Tino Sehgal,” Ligeia (2012), 198-202.

${ }^{22}$ Fourgeaud, 126.

${ }^{23}$ In this sense, Auslander's argument sounds convincing to me: 'If I may be permitted an analogy with another cultural form, to argue that Klein's leap was not a performance because it took place only within photographic space would be equivalent to arguing that the Beatles did not perform the music on their Sgt. Pepper's Lonely Hearts Club Band album because that performance exists only in the space of the recording: the group never actually performed the music as we hear it. I would consider any such claim absurd: of course the Beatles performed that music - how else are to understand it if not as a performance by the Beatles? And of course Yves Klein performed his jump' (Philip Auslander, 'The Performativity of Performance Documentation', PAJ-A Journal of Performance and Art 28, n0. 3 (2006): 7-8,.

${ }^{24}$ Even in the cases of Alÿs and Hil, the concrete fulfillment of actions in a specific space (Mexico City, in the first instance, and Central Park, in the second) is not inconsequential.

25 Peggy Phelan, Unmarked: the Politics of Performance (New York, Routledge, 1993), 149. 